\title{
Researching Media Convergence and Crossmedia News Production
}

\author{
Mapping the Field
}

IVAR JOHN ERDAL

\begin{abstract}
Digitization of production has facilitated changes in the organization and practices of journalism. Technological convergence, media convergence and organizational convergence have helped change the way in which news is made.

A substantial amount of research has been done on news production in general, and television news in particular. However, little research has been done specifically on the production context in a digital, integrated broadcasting environment, taking into account new technology and its relationship to changes in institutional context, production processes and the resulting texts.

The present article discusses some challenges that face research into media organization, challenges that are a result of these developments. The discussion is structured around two main developments: changing professional practices and genre development. The article will also look at where this line of research fits into the larger picture of media studies, and discuss the relationship to existing research in the field.
\end{abstract}

Key Words: convergence, crossmedia, news production, journalism, media organizations, broadcasting, methodology

\section{Introduction}

Digitization of production in media organizations has facilitated changes in the organization and practices of journalism. Technological convergence, media convergence and organizational convergence have changed the way in which news is made. This article discusses some challenges that face research into media organizations, challenges that are a result of these developments. What new questions have to be asked? The discussion is structured around two main developments: changing professional practices and genre development. The article will also look at where this line of research fits into the larger picture of media studies, and discuss the relationship to existing research in the field.

Over the past decade or so, fundamental changes have taken place in broadcast newsrooms. Seen from the outside, the news output of many broadcasters has expanded rapidly since the early 1990s, and covers a wide range of media platforms from television and radio to tele-text ${ }^{1}$, web and mobile phones. Subsequently, broadcasters have undergone changes in the organization and practices of production. This is perhaps most 
evident with regard to production for multiple platforms in an integrated media organization. To various degrees production for television and radio has been integrated with production for digital media. Radio and television reporters who used to exist in separate worlds, are now working together, cooperating across media boundaries. The number of reporters who are able to work for both television and radio is increasing. The platforms of radio and television have been converging in terms of production processes, and later web and other platforms such as mobile phones have been added. What specific research issues arise from this development? Related to changing professional practices, questions of how reporters relate to crossmedia strategies in their daily newswork, need to be answered. How is production for multiple media platforms conceptualized within the organization? How are news items made for and published across different media platforms? The last question is also related to genre development, as is the way in which journalists relate to news genre on different media platforms, and whether we see genre development in the form of convergence or genre hybrids.

The basis of this development is digitization of production systems, which enables content to travel across media boundaries. Television footage and radio soundbites can be published on the Web, and television sound is frequently used on radio. This development is often described using the all-encompassing term 'convergence', which covers a wide range of technological, social and cultural processes. Media researchers often describe convergence as a 'melting together' of information systems, telecommunications and media technologies, on the one hand, and social and cultural convergence, on the other. While the concept of convergence has been central in discussions of digital media developments, it is important to understand how convergence often goes hand in hand with 'divergence'. Actors, markets and technologies melt together and lay the foundation for divergence in relation to articulation and use of various media formats. As noted by Jenkins (2006:10), de Sola Pool (1983) was perhaps the first to recognize convergence as a "force of change" in the media industries, in what he describes as the "convergence of modes" (ibid:23).

The twin terms of convergence/divergence are useful for describing general developments following digitization. For the purposes of close analysis of production processes, however, I will argue that we need to look more closely at what this relationship entails. As a starting point, I will use crossmedia as a key concept. Here, crossmedia communication refers to a process whereby more than one media platform is engaged at the same time in communicating related content. Related both to convergence and divergence, I will use crossmedia production to refer to production of content for more than one media platform within the same producer or organization.

By definition, crossmedia as a concept involves two or more media platforms. In media studies, important contributions have been made on multiplatform concepts, where more platforms are engaged in the communication process in an integrated way (Syvertsen and Ytreberg, 2006). One example of this is Pop Idol, a concept that uses television as its main platform, integrated with the (mobile) phone platform for audience feedback, and with the web platform. 'Sms-television' is another multiplatform concept that uses mobile media content (sms messages, mms pictures) in a television broadcast (Enli, 2005). Currently, work is also being done on theory and practice in crossmedia production in media organizations (Bechmann Petersen and Rasmussen, forthcoming).

The form of crossmedia studied in this paper, crossmedia news production, is less integrated. Here, we are talking about production of content for more than one media platform at the same time within the same organization. Several platforms are involved. 
Not necessarily in a completely integrated way, but most often integrated to some extent. Usually, the production involves different kinds of cooperation. This may range from information sharing between journalists and desks in different platforms, via reporters producing for more than one platform, to various forms of reproduction of content for different platforms. In more advanced forms of integration and cooperation, the platforms serve different purposes in the news coverage as a whole, implying a move towards the definition of a multiplatform concept (Erdal, forthcoming).

I will argue that there is a research gap in media studies concerning media production in digital, 'crossmedia' environments. Some research has been done on crossmedia work in print media organizations (e.g. Boczkowski, 2004; Dupagne and Garrison, 2006). Regarding broadcast media, however, the lack of research is substantial, despite important contributions from, e.g., Cottle (1999), Duhe et al. (2004), Huang et al. (2006) and Bechmann Petersen (forthcoming). In the following sections, I will discuss some of the challenges of studying 'convergence journalism'. Before dealing with the question of genre in relation to crossmedia production, we will look more closely at some changes in journalistic practice that follow organizational and media convergence.

\section{Changing Professional Practices}

When looking at later developments in the services of both public service and other broadcasting institutions, the very notion of broadcasting itself becomes difficult to handle. Digitization and convergence make it increasingly difficult to distinguish between what is broadcasting and what is not (see, e.g., Scannell, 2005). As well as being more diverse in terms of content and audiences, news content now also comes in a variety of forms, delivered by online technologies in addition to traditional print and broadcasting media with enhanced, 24-hour capabilities. The field of news production has become more complex and differentiated.

According to Cottle (2003:16), few studies pursue this differentiatedness regarding news forms and journalistic practices into the production environments, and explore how news production 'contexts' and news 'texts' can be productively approached as mutually interpenetrating, and not as analytically separate elements. Some studies have tried to do this (Helland, 1993; Cottle, 1999; Clausen, 2001). Cottle (1999) studied the role of new technology in news production at the BBC's newscentre in Bristol. Looking at the introduction and impact of news technologies on journalistic practices and news output, he claims that digitization, new communication technologies and technological convergence are factors contributing to a "radical reconfiguration of broadcast newsrooms and changing professional practices" (ibid.:21).

Digital technologies and the possibilities for convergence these represent, have changed the landscape of broadcast news production. These changes have again opened the arena for 'multiskilled' 2 or 'deskilled' journalists, according to advocates and critics respectively (Cottle, 2003:16; Quinn, 2004:111). Some of these perspectives are also found in Bromley (1997). His historical account of the development of journalism in the UK, from the press to broadcasting, also deals with the term 'multiskilling'. While Bromley shows that this is not a new phenomenon - correspondents usually work for both radio and television, and small media like local newspapers have a tradition of multiskilling - he argues that digital newsrooms facilitate crossmedia work (ibid.:341).

One seemingly simple, but actually complicated question, is: What is convergence in the area of news production? Is it one, fully integrated, news desk, or should we also 
include other forms or degrees of integration and cooperation? According to Duhe et al. (2004), nine out of ten American television newsrooms are practising 'some type of convergence'. However, less than half of the respondents defined convergence as having one fully integrated newsroom. Cottle (2004:32) finds that the introduction of new technologies led to changes in the newsroom space itself, a spatial reconfiguration that significantly affected the working environment. On this point, he is supported by Boczkowski (2004:177), who argues that "materiality matters in online newsrooms". Newsrooms are sociomaterial spaces in which technical considerations affect who gets to tell the story, what kinds of stories are told, how they are told, and to what audience they are addressed. In order to improve our understanding of the relationship between changing news technologies, journalist practices and news output, Cottle (1999:26) calls for theoretically grounded, detailed empirical studies of particular news organizations.

Taking their point of departure in television, Waldahl et al. (2002) claim that conventions of (television) news production, as well as influence across media institutions and platforms, play an important role in how news content is selected and presented. This points to processes of change regarding social practices (ibid.:31). In my view, this becomes even more recognizable in a crossmedia environment, which increases the complexity of interrelationships between news media, e.g., throughout a newsday.

This line of inquiry, however, rests on a long tradition of research on media production in general, and news production in particular. Broadcast media, especially television, have been the object of extensive research within media studies, starting from the early works of Williams (1974) and Ellis (1982) on televisual form and genre development, and Brunsdon and Morley's (1978) analysis of news reception combined with textual analysis in their Nationwide study. Research into public service broadcasting has traditionally had a strong basis in normative ideals about public service media as just that, a public arena or 'offentlichkeit' (e.g., Curran, 1991), while the empirical tradition focuses on actual practice (e.g., Blumler, 1993).

A tendency in 1990s' media research has been to focus on actual, institutional practices (e.g., Helland, 1993; Søndergaard, 1994; Syvertsen, 1997; Sand and Helland, 1998; Ytreberg, 1999, Küng-Shankleman, 2000; Born, 2004). The origins of research into media institutions are typically traced to the 1960s, the time of sociologically based media research, when there was a marked interest in effects, and in how people used the media. Syvertsen (1999) identifies a movement of interest from 'effect' via 'message' to the 'sender' of the linear communication model. Researchers interested in uncovering what caused the effects, started looking at "the organisational sources and 'causes' of these features" (McQuail 1994, quoted in Syvertsen, 1999:23).

In the Nordic countries, Syvertsen (1997) and Søndergaard (1994) have contributed major works on public service broadcasting and the transition to deregulated media markets and competition. Syvertsen (1997) analyses the strategies and programming policies of the NRK and TV 2, following her comparative historical study of the NRK and the BBC (Syvertsen, 1992). Focusing on institutional processes of change, Søndergaard (1994) follows DR into the age of deregulation and competition, looking at the break-up of the monopoly and subsequent changes in programming policy and DR's position as a public service institution.

While an institutional approach has the advantage of getting close to the processes shaping text production, studies of text production have not had a central position in Norwegian media research. Research into media policy and institutional approaches have been combined to a limited degree with textual analysis (Ytreberg, 2000). From 
another angle, Waldahl et al.'s (2002) study of developments in Norwegian news broadcasting in the 1990s relies on close reading of news texts.

Ytreberg (2000:54) identifies a possible explanation for the missing development of concepts, models and methodology for studying the interplay between production and text in the scientific critique of intentionality within, e.g., literature studies, a stance he finds to be highly accepted in media studies. He points to Hall's ([1973] 1980) essay Encoding/Decoding in his attempt to construct a theoretical framework for studying the relationship between text and context. Describing how meaning structures are created both in the production and reception of a text, Hall emphasizes the reception part of the process. The essay spurred several reception studies of television texts, among others that of Brunsdon and Morley (1978). Later studies have focused on how text production as well involves interpretation on the part of the producer (Cottle, 1999; Ytreberg, 1999).

Further, Ytreberg is followed by Cottle (2003) in identifying political economy and cultural studies as the two overarching theoretical traditions dominating discussions on approaches to media organizations and their output. This "division of labour" (Ytreberg, 2000:57) emphasizes economic, political and institutional structures, and the production of meaning in the text itself, respectively. Cottle (2003:4) argues that there is also a need for other approaches, between the theoretical foci of marketplace and cultural discourses, an unexplored and under-theorised 'middle ground' of organisational structures and workplace practices. If we wish to understand why media representations look like they do, we cannot rely on textual analysis alone, Cottle claims. Thus, we need to take the production process and context into consideration.

Another reason for the gap in research on the latest developments in crossmedia text production is undoubtedly the very nature of such research. Studies of large media institutions that aim at generating thick descriptions of text production, are work intensive and require access to the institution, access that will have to be negotiated.

Having said that, research on news production processes in broadcast media is by no means a new endeavour. At the end of the 1970s, several studies of news production were published, among these Epstein (1973), Tuchman (1978), Schlesinger (1978), Golding and Elliott (1979) and Gans (1980). As Syvertsen (1999:25) argues, these studies strived to show how, and in what way, the news is made, or produced, and that the news is not simply a mirror held up to the world. In her comprehensive overview of research on media institutions, Syvertsen (1999) gives Siverts' (1984) study of news production in the newspaper Bergens Tidene credit for being the first Norwegian attempt to address this field. Puijk's (1990) empirical study of text production in NRK's educational department is a related work.

Schlesinger's (1978) seminal study of news production in the BBC is one of the first inside reports of the workings of a media institution. Working from ethnographical observations of the BBC's radio and television news departments in 1972-74, Schlesinger concerns himself with how the news is "(...)actually put together in the $B B C$ 's newsrooms" (Ibid:11).

Following in Schlesinger's footsteps, Helland (1993) has done extensive empirical work on news production at NRK and TV3. He studies the context of production and conventions of the TV news genre, aiming to "examine empirically the inter-relationship between the news texts and the news production processes in a public service and a commercial satellite television channel" (ibid.:3). Helland here focuses on the potential differences between public service and commercial news, a comparative perspec- 
tive he follows up in a study of public service news production and presentation in the NRK and the commercial competitor TV 2 (Sand and Helland, 1998). Production processes are at the centre of this study as well, as the researchers wish to get 'behind the news' (as the book's title claims) and discover not only the similarities and differences between the two channels' news broadcasts, but also what, in McQuail's (Syvertsen, 1999:23) terminology, 'causes' them. In other words, they describe the relationship between production, content and form.

Another effort in researching the practices of online news production is represented by Boczkowski (2004), who studies how daily newspapers in the US have developed electronic publishing ventures in relation to the paper-based motherships. He wants to look at the practices surrounding technological developments within established media companies (ibid.:3), the main point of interest being how new technologies challenge the work practices of media organizations and workers, and the products that result from this process. He finds, not surprisingly, that online newspapers represent a merger of conventions from the printed newspaper, and the new potentials of the Web (ibid.:17). Relating his findings to the literature on 'convergence', Boczkowski (2004:179) argues that there is too much focus on the products of convergence. Wanting to "make visible what is left unexplored by the dominant discourse around convergence" (ibid.:181), he calls for a greater focus on issues of the processes that create these products.

\section{Genre Development}

Research on digital media, often termed 'new media', is by nature multidisciplinary, combining theory and approaches from as diverse fields and traditions as film theory, art history and television theory (e.g., Bolter and Grusin, 1999), literary theory and computer science (e.g., Aarseth, 1997; Manovich, 2001). In their study of how new media 'remediate' conventions from earlier media, Bolter and Grusin (1999) stress the relationship between the rhetorics of old and new media. Furthering this approach, Fagerjord (2003) does important theoretical work in mapping what he terms 'rhetorical convergence' in the relationship between old and new media.

However, much of the rhetoric surrounding 'new media' emphasizes radical breaks from old media, and often neglects continuity (Siapera, 2004; Boczkowski, 2004). In an empirical study of what she calls 'inter-media sites' (the websites of four broadcasters: BBC, ITV, Channel4 and Channel5), Siapera (2004) seeks to identify changes and continuities in the notion of the audience. She concludes that television has indeed gone online, but not changed its understandings of audiences. In what she calls the 'struggle for dominance', television attempts to “'dominate' the internet, or at least to mark it with the televisual (...)", rather than making full use of the Internet's potential (ibid.:168). This argument is echoed by Quinn (2004:111), who argues that there exists a fundamental dichotomy between the business view of convergence, where multipleplatform publishing facilitates increased productivity and marketing, and the journalistic view, where convergence offers a potential for better journalism (something that is unlikely to save money).

A large portion of the research on digitization processes and media convergence has addressed the relationship between newspapers and online newspapers (e.g., Sparks, 2003; Boczkowski, 2004). Engebretsen's (2001) study of form and genre in online news explores the potential for utilizing hypertextuality in news presentation, specifically in the case of online newspapers. His focus is more on the possibilities of hypertextuality 
and on what online news could or should look like, rather than on actual practice. While a great deal of the research on digitization processes and media convergence has focused on the relationship between newspapers and online newspapers, research into the relationship between broadcasting and digital media is less developed.

More empirically oriented work on the development of journalistic genres in relation to emerging genres on the Internet, was done by Matheson (2004). His study of the weblog as part of The Guardian's online presence shows how online journalism deals with the specific genre of weblogs and asks further questions about the interplay between journalistic genres and emerging online formats. Weblogs have rapidly become popular with most online newspapers, as seen, e.g., in the Norwegian tabloid VG's publication of the initial postings on one of their blogs on page 3 of the paper ${ }^{3}$.

Along this line, Deuze (2003) argues that the Web has had a substantial impact on journalism as a profession as well as on journalistic culture. While he recognizes that most mainstream news media going digital repurpose not only content, but also their own journalistic culture, he claims that much of the research on journalism and new media fails to consider the current and potential connections these online journalisms can have to "broader and more profound changes and redefinitions of professional journalism and its (news) culture as a whole" (ibid.:203).

The relationship between text and genre can be seen as a framework controlling both production and reception of a text (e.g., Fairclough, 2003). The act of defining genre and separating texts into them involves the definition of a conventional framework, through identification of certain textual features. This framework directs both the production of the text, according to the established framework, and the text's reception and interpretation. Genre plays a central role both as a framework directing the production and reception of the text, and as a way of categorizing the texts and generalizing within text groups. How is the concept of genre relevant to crossmedia news production research?

Looking at the invention and revision of media texts as interconnected processes, through perspectives supplied by hermeneutics, the act of producing a text is closely related to the act of interpretation (Ytreberg, 1999:17; Bell, 1991). Here, the hermeneutics of the production process refers to what is sometimes called 'spirals of production’ or design (e.g., Liestøl, 1999:26), which means that each step in a production process relates to previous and succeeding steps, in the form of pre-understandings of the text about to be made, relations to conventions of production, medium and genre. Production of, e.g., a news reportage relies on news and genre conventions, production routines of the given institution, medium characteristics, etc. To take part in a production process, journalists will need to have knowledge of existing news texts, and share an understanding of the genre involved (Ytreberg, 1999:17). The tight deadlines and time pressures of news production make it relatively dependent on established production routines and (genre) conventions (e.g., Schlesinger, 1978:83; Tuchman, 1978).

Helland's (1993) approach to television news production analysis and the concept of genre is to see news as a broad subgenre of the epic genre ${ }^{4}$. He relies on Williams (1977) in further dividing television news into subgenres according to the mode of formal composition. Williams distinguishes between a genre's stance, mode of formal composition, and appropriate subject matter. Following this, Helland identifies the familiar subgenres bulletin, editorial comment, news report, and interview (Helland, 1993:90), all with more detailed subsets ${ }^{5}$.

While not conceptualized in the way described above, the difference between static and dynamic information types is an issue in Crisell's (1986) study of the medium-spe- 
cific semiotics of radio news. While he does not define genre in relation to radio news, he discusses concrete differences between radio news and newspapers with respect to both content and format (ibid.:103).

One problem in dealing with genre in a crossmedia context involving web communication is that it becomes difficult to distinguish between what is a medium and what is a genre. In his work on the 'architext', Genette (1992) operates with a genre understanding similar to that of Williams, distinguishing between aspects of theme, mode of enunciation and 'medium' of imitation. This is taken as a point of departure by Fagerjord (2003) in a discussion of whether it is useful to distinguish between web media and web genre. He argues that the Web should not be regarded as a medium, but rather a platform capable of carrying a variety of media (ibid.:13-16).

If we accept this, we still run into difficulties. One aspect that to a certain degree distinguishes crossmedia text production involving web media in the area of broadcasting, from that of print-based media, is the meeting between static and dynamic information types ${ }^{6}$. Online news originating in newspapers is increasingly more complex in nature, and the use of video material is increasing. However, print and images are still the primary content of print-based media organizations. The main content or information type of broadcast media, on the other hand, is dynamic media like audio and video. In a crossmedia environment, this means greater complexity with regard to how this dynamic content is republished on the Web, alongside text and still images.

\section{Conclusions}

Convergence has changed the way in which news is made. Digitization and technological convergence mean that the boundaries of media platforms are easier to cross. Content can easily be shared between journalists making news for television, radio and the Web. Media organizations increasingly integrate production for different media platforms, in order to encourage cooperation between desks.

The main purpose of the present article has been to identify gaps in media studies as regards crossmedia production. These research gaps concern changing professional practices and genre development in relation to changes in the organization and practices of news journalism for multiple media platforms in an integrated or converged organization.

The article has identified some research questions that need to be investigated. With respect to changing professional practices, how do reporters relate to crossmedia strategies in their daily newswork? How is production for multiple media platforms organized, practiced and conceptualized within the organization? How are news items made for and published across different media platforms? This also relates to genre development. Other questions ripe for study concern the way in which journalists work with news genres on different media platforms, and whether cooperation across media platforms is followed by genre development.

\section{Notes}

1. By the term 'tele-text' I refer to text-based services via television, e.g. the Norwegian Tekst-tv and the British Ceefax.

2. i.e. journalists (skilled to be) working on several media platforms in a multi-media work environment.

3. http://blog.vg.no/index.php?blogId=6. 
4. From Aristotle's definitions of the epic, lyric and dramatic genre (Ibid.).

5. A subgenre can also contain another (e.g. interview(s) in a news report).

6. By dynamic information types, I mean audio and video, conditioned by temporal sequence, and changing over time in order to convey meaning. Static information types are text and still images, constant over time (Liestøl, 1999:44).

\section{References}

Barthes, Roland (1977) 'The Death of the Author', in Roland Barthes: Image - Music Text. Fontana/Collins. Bechmann Petersen, Anja (forthcoming) Cross-media Production - Interplay between Media Platforms. University of Aarhus.

Bechmann Petersen, Anja og Rasmussen, Steen K. (eds.) (2007) På tvars af medier. AJOUR (forthcoming). Bell, Allan (1991) The Language of News Media. Oxford: Blackwell.

Boczkowski. Pablo J. (2004) Digitizing the News. Innovation in Online Newspapers. Cambridge, MA: The MIT Press

Bolter, Jay David \& Richard Grusin (1999) Remediation - Understanding New Media. Cambridge MA: The MIT Press.

Born, Georgina (2004) Uncertain Vision. Birt, Dyke and the Reinvention of the BBC. London: Secker \& Warburg.

Blumler, Jay (1993) 'Meshing Money with Mission: Purity Versus Pragmatism in Public Broadcasting', in European Journal of Broadcasting Vol. 8 no. 4.

Bromley, Michael (1997) 'The End of Journalism? Changes in Workplace Practices in the Press and Broadcasting in the 1990s', in Michael Bromley \& Tom O'Malley: A Journalism Reader. London: Routledge, pp330-361.

Brunsdon, Charlotte og David Morley (1978) Everyday Television: Nationwide, BFI Television Monographs No. 10, British Film Institute.

Clausen, Lisbeth (2001) Global News Production. Copenhagen: Copenhagen Business School Press.

Cottle, Simon (2003) (ed.) Media Organization and Production. London: Sage.

Cottle, Simon (2001) 'Contingency, Blunders, and Serendipity in News Research: Tales from the Field', Communications: The European Journal of Communications Research 26 (2).

Cottle, Simon (2000) 'New(s) Times: Towards a 'Second Wave' of News Ethnography', Communications: The European Journal of Communications Research 25 (1).

Cottle, Simon (1999) 'From BBC Newsroom to BBC Newscentre - on Changing technology and journalist practices', Convergence. The International Journal of Research into New Media and Technologies 5 (3).

Cottle, Simon (1998) 'Participant Observation: Researching News Production', in A. Hansen, S. Cottle, R.Negrine, C. Newbold, Mass Communication Research Methods. Basingstoke: Macmillan.

Curran, James (1991) 'Rethinking the Media as Public Sphere', in Dahlgren and Sparks (eds.) Communication and Citizenship: Journalism and the Public Sphere in the New Media Age. Routledge.

Deuze, Mark (2002) The Internet and Its Journalisms - Considering the Consequences of Different Types of News Media Online, paper for IAMCR Conference.

Duhe, Sonya Forte, Melissa Mortimer and San San Chow (2004) 'Convergence in TV Newsrooms: A Nationwide Look', Convergence vol 10 no. 2.

Eide, Martin (1992) Nyhetens interesse: Nyhetsjournalistikk mellom tekst og kontekst, Oslo: Universitetsforlaget.

Ellis, John (1988) Visible Fictions: Cinema - Television - Video. Routledge.

Ellis, John (1999) Seeing Things. Television in the Age of Uncertainty. London: Tauris.

Engebretsen, Martin (2001) Nyheten som hypertekst. Tekstuelle aspekter ved møtet mellom en gammel sjanger og ny teknologi. IJ-forlaget.

Enli, Gunn (1998) Nyhetsproduksjon og bedriftskultur. En komparativ analyse av NRKs Dagsnytt Atten og P4s Sytten tretti: Universitetet i Oslo: Institutt for Medier og Kommunikasjon, Hovedoppgave.

Epstein, Edward Jay (1973) News from Nowhere: Television and the News. New York: Vintage Books.

Erdal, Ivar John (forthcoming) 'Lokomotiver og sugerør. Om medieplattformenes roller i en allmennkringkasters nyhetsorganisasjon', in Bechmann Petersen and Rasmussen (2007) På tvars af medier.

Erdal, Ivar John (forthcoming) 'Researching Media Convergence and Crossmedia News Production. Mapping the Field', Nordicom Review. 
Erdal, Ivar John (2000) Navigating the Network - on the Theorisation of Interactivity and Hypermedia. University of London: Goldsmiths College, M.A. Dissertation.

Erdal, Ivar John (2001) Handlingens estetikk - en analyse av leserrollen i tre hypertekster. Universitetet $\mathrm{i}$ Oslo: Institutt for Medier og Kommunikasjon, Hovedoppgave.

Fagerjord, Anders (2003) Rhetorical Convergence: Earlier Media Influence on Web Media Form. Universitetet i Oslo: Acta Humaniora, Dr.art.-avhandling.

Fairclough, Norman (2003) Analysing Discourse. Textual Analysis for Social Research. Routledge.

Gans, Herbert (1979) Deciding what's News: A study of CBS Evening News, NBC Nightly News, Newsweek and Time. New York: Pantheon Books.

Geertz, Clifford (1973) 'Thick Description. Toward an Interpretive Theory of Culture', in Geertz, Clifford: The Interpretation of Cultures. Selected Essays. Harper Collins, Basic Books, pp3-30.

Genette, Gerard (1992) The Architext: An Introduction. Berkeley: University of California Press.

Golding, Peter and Phillip Elliott (1979) Making the News. London: Longman.

Hall, Stuart ([1973] 1980) 'Encoding/Decoding', in Hall et al: Culture, Media, Language: Working Papers in Cultural Studies, 1972-79. Routledge.

Helland, Knut ([1993] 1995) Public Service and Commercial News: Contexts of Production, Genre Conventions and Textual Claims in Television. Universitetet i Bergen: Institutt for medievitenskap, Rapport nr. 18.

Hendy, David (2000) Radio in the Global Age. Polity press.

Küng-Shankleman, Lucy (2000) Inside the BBC and CNN. Managing Media Organisations. New York: Routledge.

Liestø1, Gunnar (1999) Essays in Rhetorics of Hypermedia Design. Universitetet i Oslo: Institutt for Medier og Kommunikasjon, Dr. philos- avhandling.

Liestøl, Gunnar, Morrison \& Rasmussen (ed) (2003) Digital Media Revisted. MIT Press.

Manovich, Lev (2001) The Language of New Media. The MIT Press.

Matheson, Donald (2004)'Weblogs and the Epistemology of the News: Some Trends in Online Journalism', New Media \& Society, Vol 6. No 4 (pp443-468).

Morley, David (1980) The 'Nationwide' Audience: Structure and Decoding, BFI TV Monographs No. 11, London.

Morley, David (1986) Family Television. London: Comedia.

Murray, Janet (1997) Hamlet on the Holodeck - The Future of Narrative in Cyberspace. New York: The Free Press.

Pavlik, John (2001) Journalism and New Media. New York: Columbia University Press.

Puijk, Roel (1990) Virkeligheter i NRK: Programproduksjon i fjernsynets Opplysningsavdeling. Lillehammer, eget forlag.

Quinn, Stephen (2004) 'An Intersection of Ideals: Journalism, Profits, Technology and Convergence', Convergence. The International Journal of Research into New Media and Technologies 10 (4) pp109124.

Rasmussen, Terje (2002) Nettmedier - Journalistikk og medier på Internett, Fagbokforlaget.

Sand, Gunnar \& Knut Helland (1998) Bak TV-nyhetene: Produksjon og presentasjon i NRK og TV2. Bergen: Fagbokforlaget.

Scannell, Paddy (ed.) (1991) Broadcast Talk. London: Sage publications.

Scannell, Paddy and David Cardiff (1991) A Social History of British Broadcasting. Oxford: Blackwell.

Scannell, Paddy (1996) Radio, Television and Modern Life. Oxford: Blackwell.

Schlesinger, Philip (1987) Putting "Reality” Together: BBC News. Methuen.

Schudson, Michael (1995) The Power of News. Harvard University Press.

Siapera, Eugenia (2004) 'From Couch Potatoes to Cybernauts? The Expanding Notion of the Audience on TV Channels' Websites', New Media \& Society 6 (2) pp155-172.

Siverts, Ola B. (1984) Nyheter i BT? Endrings- og vedlikeholdsprosesser $i$ Vestlandets storavis. Universitetet i Bergen: Sosialantropologisk institutt, Magistergradsavhandling.

Syvertsen, Trine (1992) Public Service in Transition. A Comparative and Historical Analysis of the BBC and the NRK. PhD-thesis. Centre for Mass Communication Research, Leicester University. Levende Bilder nr. 5/92. Oslo: NAVF.

Syvertsen, Trine (1997) Den store TV-krigen: Norsk allmennfjernsyn 1988-96, Fagbokforlaget.

Syvertsen, Trine (1999) 'Medieinstitusjoner som forskningsfelt: tendenser i norsk Kringkastingsforskning', Norsk medietidsskrift (2).

Syvertsen, Trine (2003) 'Challenges to Public Television in the Era of Convergence and Commercialisation', Television and New Media Vol. 4 No. 2, May 2003 (155-175).

Søndergaard, Henrik (1994) DR i tv-konkurrencens tidsalder. Fredriksberg: Samfundslitteratur. 
Søndergaard, Henrik (2000) Does Public Service Broadcasting have a Role to Play in the Digital Age?, Working Paper No. 5, Global Media Cultures, København.

Tuchman, Gaye (1978) Making News: A Study in the Construction of Reality. New York: Free Press.

Waldahl, Ragnar, Michael Bruun Andersen and Helge Rønning (2002) Nyheter først og fremst. Norske tvnyheter: myter og realiteter, Oslo: Universitetsforlaget.

Williams, Raymond ([1974] 2003) Television. Technology and Cultural Form. London: Fontana.

Ytreberg, Espen (1999) Allmennkringkastingens autoritet: Endringer i NRK Fjernsynets tekstproduksjon. Universitetet i Oslo: Institutt for medier og kommunikasjon, Dr.art.-avhandling.

Ytreberg, Espen (2000) 'Notes on Text Production as a Field of Inquiry in Media Studies', Nordicom Review (2).

Ytreberg, Espen (2001) Programskjemaarbeid i NRK Fjernsynet: Beslutningsprosesser i et maktsentrum. Universitetet i Oslo: Institutt for medier og kommunikasjon.

Aarseth, Espen (1997) Cybertext - Perspectives on Ergodic Literature. Johns Hopkins University Press.

IVAR JOHN ERDAL, Cand.Philol., Researcher, Department of Media and Communication, University of Oslo, P.O. Box 1093 Blindern, N-0317, i.j.erdal@media.uio.no 